\title{
The Bioinformatic and Expression Analysis of PSMD4 Gene
}

\author{
PSMD4 Geninin Ekspresyonu ve Biyoinformatik Analizi
}

\author{
Research Article
}

Sümeyye Aydogan Turkoglu*, Gizem Güler, Feray Köçkar

Department of Molecular Biology and Genetics, Faculty of Science and Literature, Balikesir University, Balıkesir, Turkey.

\section{A B S TR AC T}

$6 \mathrm{~S}$ proteasome non-ATPase subunit 4 (PSMD4) that has a molecular weight of $41 \mathrm{kDa}$ is included on chromosome 1 (1q21.3). PSMD4 protein is a subunit of the $19 \mathrm{~S}$ regulatory region in the $26 \mathrm{~S}$ proteasome. The proteasome breaks down proteins that are not needed or non-functional in the cell. We have limited data about the regulation of this gene in the literature. In our research, changes in the mRNA and protein levels of the PSMD4 gene were investigated in different cancer cell lines (prostate, breast, colon, cervix, hepatoma, osteosarcoma and pancreas) and a normal cell (human vein endothelial cell). The highest expression of PSMD4 gene was seen in HUVEC and PC-3 cells. Bioinformatic analysis was also performed on PSMD4 protein for different species namely human, mouse and rat. Our Bioinformatic analyses showed that first 250 nucleotides are much conserved in all three species.

\section{Key Words}

PSMD4, cancer, cell lines, bioinformatics.

\section{öz}

$6 S$ proteazom non ATPaz subunit 4 (PSMD4) kromozom 1'in q kolunun 21.3 bölgesinde lokalize olmuştur ve 41

Kda moleküler ağırlığında protein kodlamaktadır. PSMD4, 26S proteazomun yapı birimi olan 19S düzenleyici yapı biriminde görev yapmaktadır. Proteozomun ana görevi intiyaç duyulmayan işlevini yitirmiş ya da zarar görmüş proteinlerin yıkımıdır. Literatürde çok işlevli protein olan PSMD4 ve onun regülasyonu hakkındaki bilgiler oldukça sınırlıdır. Bu çalışmada; PSMD4'ün mRNA ve protein seviyesindeki ekspresyonu çok sayıda kanser hücre hattında (prostat, meme, kolon, servik, hepotoma, kemik ve pankreas kanseri) ve bir normal hücrede (Göbek kordonu epitel hücresi) incelenmiştir. PSMD4 mRNA ve protein seviyesindeki ekspresyonu PC-3 ve HUVEC hücre hatlarında en yüksek seviyede elde edilmiştir. Ayrıca PSMD4 proteinin insan, fare ve tavşan gibi farklı türlerdeki biyoinformatik analizleri 3 türde ilk 250 amino asit benzer olduğunu ve korunduğu göstermiştir.

\section{Anahtar Kelimeler}

PSMD4, kanser, hücre hattı, biyoinformatik.

Article History: Received: Aug 21, 2017; Revised: Feb 12, 2018; Accepted: Jul 31, 2018; Available Online: Oct 4, 2018. DOI: $10.15671 /$ HJBC.2018.241

Correspondence to: S. Aydogan Turkoglu, Dept. of Mol. Biol. and Gen., Fact. of Sci. and Literature, Balikesir Uni., Balıkesir, Turkey. 


\section{INTRODUCTION}

A fter losing the functional activity of proteins in the cell, proteins are required for demolishing. In eukaryotic cells, these proteins are destroyed using lysosomal and proteasomal pathways [1]. The greatest destruction pathway is proteasomes located in the nucleus and the cytoplasm and degraded unneeded or damaged proteins Proteasomes are present in all eukaryotic cells, in archaea and also in some bacterial cells [2].

Proteasomes are responsible for destroying proteins that have completed their function. Proteins to be digested should be distinguished from those that will not be destroyed. To solve this problem, ubiquitin is marked by binding to proteins to be destroyed. The $26 \mathrm{~S}$ proteasome 195 regulatory tag opens the folds by recognizing ubiquitin-labelled proteins and sends them proteasome for destruction [1]. The cytosolic 26S proteasome composed of the $20 \mathrm{~S}$ proteasome and the $19 \mathrm{~S}$ is used to degrade the polyubiquitinated one and is a short-lived and unneeded protein in mammals [3]. PSMD4 (26S proteasome nonATPase subunit 4) gene encodes an ubiquitin binding protein S5a which serves the 19S regulatory complex and also exists in the soluble form in the cytosol. PSMD4 gene also encodes ASF (Anti-secretory Factor) and Angiocidin. The $\mathrm{S} 5 \mathrm{a}$ is a protein located in the proteasomal subunit $26 \mathrm{~S}$ and linked to the polyubiquitinated chains by two ubiquitin binding motifs. The ASF protein is similar in sequence to $\mathrm{S} 5 \mathrm{a}$ but is quite different concerning function. It regulates intestinal fluid that is induced by cholera toxin, and Angiocidin is a protein that is over-expressed in various solid tumours and tumour-capillary endothelial cells. Angiocidin has an anti-angiogenic activity and inhibits tumour growth [4]. Angiocidin protein sequence has a high-level homology with S5a and ASF. The carboxy-terminal region of angiocidin carries an additional three amino acids, unlike the other two proteins, S5a and ASF [5].

PSMD4 gene is a multifunctional protein but there is no cancer-related regulation about this gene in the literature. Therefore, the purpose of the present research is identifying expression level of this gene in different cancer cells and a normal cell model. We analyzed the
mRNA and protein expression of PSMD4 gene in various cancer cells, namely, PC-3 and DU-145, i.e. Prostate cancer cells; MG-63 and Saos-2, i.e. Human Osteosarcoma; MCF-7, i.e. Human Breast Carcinoma; Hela, i.e. Human Cervical cancer; HT-29, i.e. Human Colon Carcinoma; PANC, i.e. Pancreatic cancer; Hep-3B, i.e. Hepatocellular cancer, and in a normal cell, HUVEC, i.e. Human Umbilical ENDOTHELIAL. Taken that PSMD4 gene encodes three different functional proteins, it is important to analyse the structure of gene and protein sequence amongst the species. Therefore, we also analysed gene and protein sequences of human, mouse and rat PSMD4 in a bioinformatical manner.

\section{MATERIALS and METHODS Materials}

All chemicals used in the studies are suitable for molecular biology studies. Molecular biology materials, chemicals and enzymes used in RTPZR studies were obtained from Biochrom, Sigma, Merck, Fermentas, Thermo Scientific and Promega. Primers used in the study were purchased from Macrogen. Detailed information about the cell lines used in the study can be found in our previous publications [6-8]. An antibody against PSMD4 was bought from Santa Cruz (sc53425). $\beta$-actin (sc-81178) and anti-mice IgHRP, i.e. A5441 were purchased from Sigma-Aldrich. Primers used in this research were obtained from Macrogen.

\section{Cell Culture}

All cells used in the research were grown in DMEM medium (Invitrogen) containing $2 \mathrm{mM}$ L-Glutamine and $10 \%$ heat inactivated $\left(56^{\circ} \mathrm{C}\right.$ for 1 h) Fetal Calf Serum. Cells were monitored for growth by placing the incubator containing 5\% $\mathrm{CO}_{2}$ at $37^{\circ} \mathrm{C}$. Control of cell viability was carried out under Trypan Blue Microscopy. The cell lines were grown and routinely passaged twice a week [6].

\section{RNA Preparation and Semi Quantitative RT- PCR}

Cells were grown in $25 \mathrm{~cm}^{2}$ flasks and were centrifuged at $10,000 \mathrm{rpm}$ for 5 minutes to obtain pellets. Cell pellets were used for RNA isolation. Isolation was performed from pellets 
using the Thermo Scientific RNA isolation kit. RNAs were stored at $-80^{\circ} \mathrm{C}$ in the freezer for long periods. RT-PCR was used in two separate steps. In the first step, reverse transcriptase (RT) was used for cDNA synthesis. In the second step, amplification of the gene region and Polymerase Chain Reactions (PCR) were carried out by using CDNA obtained from the first step with gene specific primers. The PCR conditions and the primer sequences for PSMD4 are given in Table 1 and 2. PCR products were run on a $1 \%$ $(\mathrm{w} / \mathrm{v})$ agarose gel and analyzed in the Gel-Doc system. Densitometric analyses were performed with Image $J$, and the expression of PSMD4 was normalized by $\mathrm{Hb} 2$ ( $\beta-2$ microglobulin) expression.

\section{Western Blot}

Proteins of each cell lines were extracted by applying RIPA buffer. The $50 \mu \mathrm{g}$, protein extract, was applied on a $10 \%$ polyacrylamide gel and was transferred to PVDF membranes (Millipore).

Table 1. Primer information used for the research.
Membranes were then blocked in solution (1xTris buffered saline (TBS) containing $5 \%(\mathrm{w} / \mathrm{v})$ fatless milk-powder and $0.1 \%(\mathrm{v} / \mathrm{v})$ Tween-20) to prevent non-specific binding. Membranes were first treated with primary antibody PSMD4 (Santa Cruz, sc-53425) for $1 \mathrm{~h}$ at room temperature, and after three times of washing, with secondary antibody (HRP-conjugated anti-mouse) for $1 \mathrm{~h}$ (room temperature). Membranes were treated with chemiluminescence substrate (Pierce) and transferred to film. Correct size bands were analysed with markers. The Image J Software was used to analyse the bands. The PSMD4 protein amount was normalised by the amount of $\beta$-Actin protein.

\section{Bioinformatic Analysis}

The mRNA and protein sequences of mouse (NM_001282017.1), human (NC_000001.11) and rat (NM_031331.1) PSMD4 gene were obtained from $\mathrm{NCBI}$ database. Mouse, Human and Rat PSMD4 gene sequences were compared by BioEdit v.7.2.5 program.

\begin{tabular}{|c|c|c|c|c|c|}
\hline $\begin{array}{l}\text { Primer } \\
\text { Name }\end{array}$ & $\begin{array}{l}\text { Primer } \\
\text { sequence }\end{array}$ & $\begin{array}{l}\text { Accession } \\
\text { no }\end{array}$ & $\begin{array}{l}\text { Product } \\
\text { size }\end{array}$ & GC (\%) & $\begin{array}{c}\text { Temperature } \\
\left({ }^{\circ} \mathrm{C}\right)\end{array}$ \\
\hline $\begin{array}{l}\text { PSMD4 } \\
\text { Forward }\end{array}$ & 5' GAAGGTGGCAAGATG GTGTTGGAAA3' & NM_002810.2 & $380 \mathrm{bp}$ & 48 & 56 \\
\hline $\begin{array}{l}\text { PSMD4 } \\
\text { Reverse }\end{array}$ & 5' TCCTTCTCATTGTCCTCCACTGGGCT 3' & NM_002810.2 & $380 b p$ & 53.8 & 56 \\
\hline $\begin{array}{l}\mathrm{H} \beta-2 \\
\text { Forward }\end{array}$ & 5' TTTCTGGCCTGGAGGCTATC 3' & NM_004048 & $314 \mathrm{bp}$ & 55 & 52 \\
\hline $\begin{array}{l}\mathrm{H} \beta-2 \\
\text { Reverse }\end{array}$ & 5' CATGTCTCCATCCCACTTAACT 3' & NM_004048 & $314 \mathrm{bp}$ & 47.6 & 52 \\
\hline
\end{tabular}

Table 2. PCR conditions for PSMD4.

\begin{tabular}{cccc}
\hline Steps & $\begin{array}{c}\text { Temperature } \\
\left({ }^{\circ} \mathrm{C}\right)\end{array}$ & Time $(\mathrm{sec})$ & Cycle \\
\hline 1 & 94 & 180 & 1 \\
\hline 2 & 94 & 45 & 35 \\
\hline & 56 & 45 & 1 \\
\hline 3 & 72 & 45 & \\
\hline
\end{tabular}




\section{RESULTS and DISCUSSION}

\section{Expression Analyses of PSMD4 in Selected Cells}

PSMD4 mRNA expression level was analyzed using Semi-quantitative Reverse TranscriptionPolymerase Chain Reaction (RT-PCR) strategy. The sq-rt-PCR analysis was performed with specific primers to PSMD4 (Table 1). In expression analysis, the $\mathrm{H} \beta-2$ gene from housekeeping genes was used to normalize our gene values. In our laboratory, there are specific primers of this gene that we frequently use in our analyzes, and they were tested in our experiments. The PCR products were visualized on an agarose gel, and the bands in the gel were analyzed by Image $J$ program (Figure 1). As seen in Figure 1, the maximum PSMD4 expression was obtained from PC3 and HUVEC cells.

\section{PSMD4 Protein Analysis in PC-3, HUVEC, SAOS-2, HEP3B Cells by Western Blotting} We investigated the protein level of PSMD4 gene in the cells with highest PSMD4 mRNA expression using the Western Blotting Method. Determining of the protein level of PSMD4 provides relevant

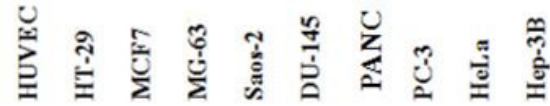

PSMD4

Hß2

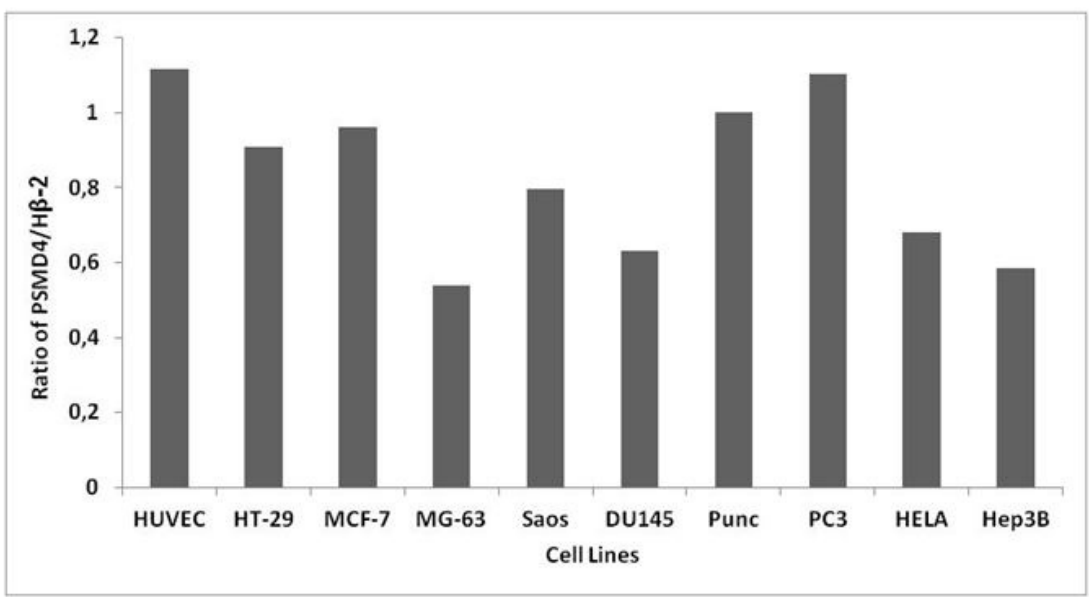

Figure 1: Analysis of mRNA level of PSMD4 gene in different cell lines. Products were obtained with RT-PCR and run on agarose gel. The bands were analysed with Image J. PSMD4 mRNA level was normalized to HB2 level.
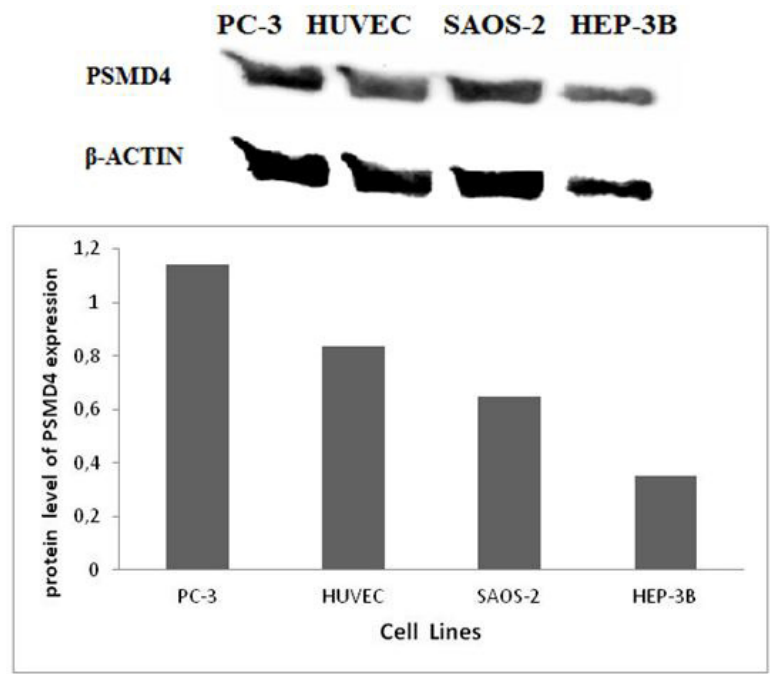

Figure 2: The Western Blot Technique was used for analysis at the PSMD4 protein level in PC-3, HUVEC, SAOS-2, HEP3B cancer cell lines. Image $j$ was used to analyse the bands. $\beta$-Actin was used for normalisation. 
information about the comparison of the mRNA level. PSMD4 protein was analysed in PC-3, HUVEC, Saos-2, Hep3B cells by Western Blotting. The mRNA expression Human prostate cancer cells (PC-3) and HUVEC cells have the maximum protein level of PSMD4 gene.

\section{In silico Analysis of Human, Mouse, and Rat PSMD4 Protein}

Homo sapiens PSMD4 gene is 1332 bp in length. It is placed on chromosome 1 , and contains 10 exons. Mus musculus PSMD4 gene is $1344 \mathrm{bp}$ in length. It is placed on chromosome 3 , and contains 10 exons. Ratus norvegicus PSMD4 gene is 1334 in length. It is placed on chromosome 2. Accession numbers of mRNA of these genes are; Homo sapiens PSMD4 gene NC_000001.11, Mus musculus PSMD4 gene NM_001282017.1, Ratus norvegicus PSMD4 gene NM_031331.1. PSMD4 sequence analysis of the different species has shown us that there are some differences between selected mammalian species. For example, human and mouse protein sequences are $96 \%$ similar, whereas human and rat protein sequences are $99 \%$ identical. There is also a $97 \%$ similarity between mouse and rat sequences.

In a human PSMD4 protein, essential for ubiquitin-binding sites, LALAL and IAYAM amino acids are detected in 216-220; 287-291, respectively (Figure 3 ). In human sequence, 197262 amino acids are also related to ubiquitin interacts with ubiquitylated proteins and proteasome via ubiquitin-like domains and ubiquitin-associated domains. In human, there are two different protein variants of PSMD4. PSMD4 variant 1 and angiocidin have 380aa, whereas PSMD 4 variant 2 has 377 aa with the exemption of 255-257 amino acids. The role of these three additional amino acids is not known. They could play roles for differential activity of the protein. Our Bioinformatics analyses showed that the first 250 nucleotides were much conserved in all three species (Figure 3). S5a and ASF have identical 377 amino acid (aa) sequences, while Angiocidin is described as having an additional three amino acid sequence, namely, Gly255Glu256Arg257 in its C-Terminus.

\section{DISCUSSIONS}

In the cell, protein must be destructed after losing its functional activity or when it is damaged. In eukaryotic cells, there are two pathways for destruction, lysosomal or proteasomal pathways [1]. Proteasome (a multisubunit enzyme complex) plays important roles in the regulation of proteins controlling cell-cycle progression and apoptosis. For this reason, it has become an important target for anticancer therapy. Before the degradation of the protein, this specific protein is firstly flagged for destruction by the ubiquitin conjugation system (which, in the end, results in the attachment of a polyubiquitin chain to the targeted protein [2]. There are many types of the proteasome in a eukaryotic cell. Most specifically in mammals is the cytosolic 26S proteasome

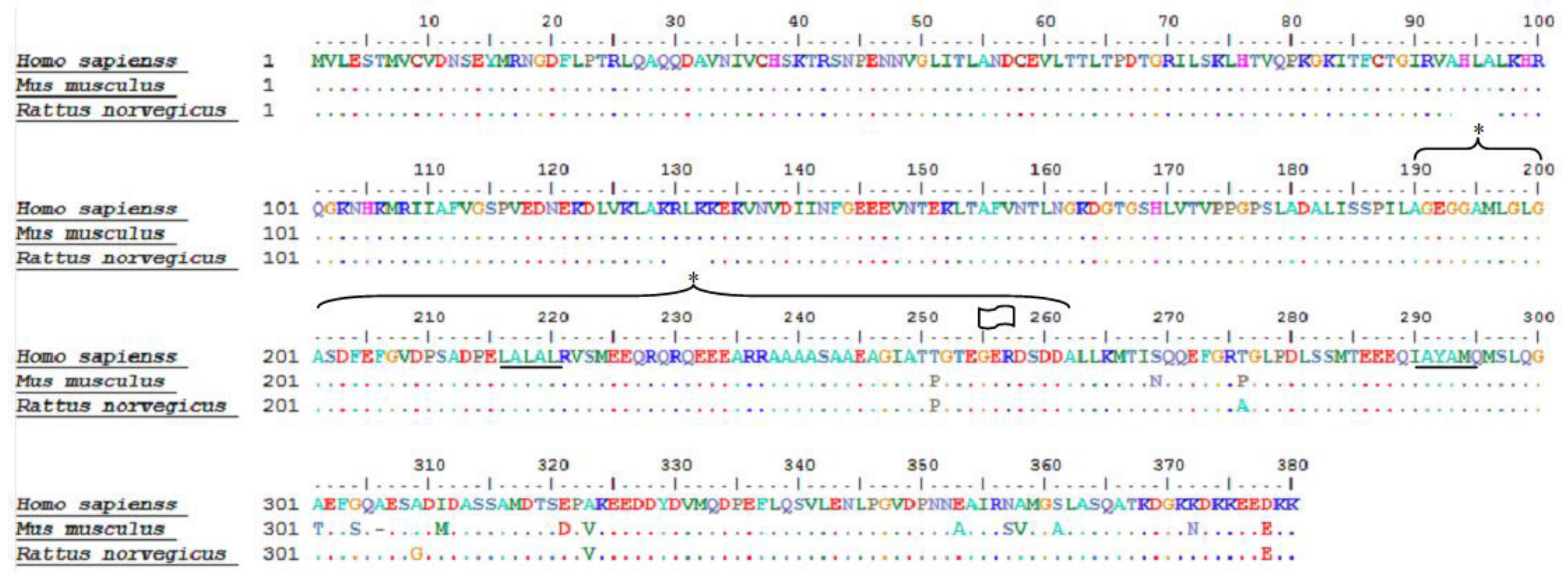

Figure 3: In Silico Analysis of PSMD4 Proteins in Different Species: Essential for ubiquitin-binding, *:197-262aa Ubiquitin is associated with ubiquitin and interacts with ubiquitinated proteins and proteasome via ubiquitin-like domains, Angiocidin has an additional three amino acids, GER). 
and it is approximately $2000 \mathrm{kDa}$. Center of $26 \mathrm{~S}$ proteasome has one core $20 \mathrm{~S}$ particle and two regulatory subunits [9].

Another element in proteasomal degradation is the amino acid sequences contained in proteins. Some amino acid sequences make proteins more vulnerable to degradation and determine the half-life of the protein. These are the 'PEST' series. The PEST sequence is a peptide chain rich in Proline, Glutamic acid, Serine, and Theronin. This sequence is associated with proteins having a short half-life in the cell. The amino acids in the PEST sequence are positively charged. PEST sequences are thought to be a signal peptide for protein degradation [1-2]. Another element of protein destruction is the ' $\mathrm{N}$ end rule' which was discovered in 1986 by Alexander Varshavsky and his colleagues. This rule is related to ubiquitination. The time from the $\mathrm{N}$-terminal amino terminal of a rule protein to its complete destruction is the half-life of this protein. However, the duration of the destruction of amino acids in eukaryotic and prokaryotic organisms is changing. Amino acid modification and variants found in the $\mathrm{N}$-terminal can cause this difference. However, the half-life of proteins can be deduced from this rule as an estimate [3].

The destruction of a protein by the ubiquitinproteasome pathway begins with two steps: the first step is the covalent attachment of the target substrate to multiple ubiquitin chains. The combination of ubiquitin and proteins to be destroyed may include cell cycle control, DNA repair, biosynthesis of ribosome-like organelles, $\mathrm{MHC}$ class 1antigen presentation and inflammatory response, endocytosis of cell surface proteins and modulation of ion channels, morphogenesis of neuronal networks, Nf- Regulation, long-term memory and biorhythm formation, apoptosis, differentiation, stress response and protein quality. The second step in the ubiquitinproteasome pathway is the degradation of the ubiquitin-releasing protein, releasing ubiquitin. Some of the ubiquitin system targets receptors of cancer-stimulating growth factors such as $\mathrm{N}$-myc c-fos, c-jun, Src and EGFR, or even direct tumour suppressor proteins [10].
PSMD4 (26S proteasome non-ATPase subunit $\mathrm{S} 5 \mathrm{a}$ ) encodes one of the three proteins that serve the 19S regulatory complex. PSMD4 gene also encodes ASF and Angiocidin. The protein S5a is placed in the $26 \mathrm{~S}$ proteasome subunit. It is a major protein polyubiquitin recognition domain. On the other hand, anti-secretory factor, a protein whose sequence is identical to $\mathrm{S} 5 \mathrm{a}$, is a protein that regulates intestinal fluid transport which is induced by cholera toxin. More important than this, Angiocidin is a protein that is expressed excessively in various solid tumours and tumour capillary endothelial cells. It inhibits angiogenesis and tumour growth [4]. In 1993, Tuszynski et al. isolated a new TSP-1-binding protein, angiocidin. It has been shown that a tumour is expressed in excess in the stroma and that a tumour is active in the progressive mechanisms. This protein is described as a potent inhibitor of angiogenesis and tumour growth. It inhibits angiogenesis by binding to collagen and collagen receptors. It also causes the differentiation of monocytes into macrophages in THP1, a cell line of monocytic leukaemia. This differentiation occurs at the same time with the dramatic changes in cell morphology and the macrophage marker expression. It has also been reported that angiocidin treatment may enhance the ability of monocytes to present antigens to $T$ lymphocytes and lead to the destruction of tumour cells (directly or indirectly) by functional macrophages [11].

Angiocidin protein sequence has a highlevel homology with other proteins (S5a and antisecretory factor) (both have identical sequences). Angiocidin differs from them with 3 additional amino acids (located in carboxyl terminus) [5]. There are so many research in the literature about cancer and this two proteins, $\mathrm{S} 5 \mathrm{a}$ and Angiocidin. But the working mechanism of these proteins could not be explained exactly yet.

PSMD4 mRNA or protein expression were shown in some cell lines, THP-1, i.e. acute monocytic leukemia cell line; MCF-7, i.e. breast cancer cell line; H1299, i.e. human non-small cell lung carcinoma cell line; HeLa, i.e. cervical cancer cells; Colo320, i.e. Dukes' type C, colorectal adenocarcinoma cell line; LoVo, i.e. Colorectal 
Adenocarcinoma cells [11-15]. In our research, we want to show the expression profile of PSMD4 gene in different cancer cell lines and a normal cell. In this research, PSMD4 mRNA expression levels were determined by sq RT-PCR analysis. PSMD4 expression was determined in osteoblastic cancer cells, cervix cancer cells, colon cancer cells, prostate cancer cells, breast cancer cells, hepatocellular cancer cells, pancreatic carcinoma cells and an in healthy cells. Among the investigated cell lines, PSMD4 mRNA was found most abundant in PC-3 and HUVEC cell line. As a similar prostate model, DU-145 has lower expression level than PC-3. PC-3 cells have a high metastatic potential whereas DU-145 cells have a medium-level metastatic potential $[16,17]$.

Among all the cell lines investigated, the PSMD4 mRNA ve protein level was detected to be at the highest level in the PC3 cell line. These findings would be useful for choosing the cell model for PSMD4 gene regulation studies in different cancers.

Bioinformatic analyses showed that there are two transcript variants of PSMD4 gene. Variant 1 refers to the longer transcript. It encodes the longer isoform (380aa). Variant 2 uses an alternate in-frame splice junction when compared to variant 1 . The isoform 2 has the same $\mathrm{N}$ - and C-termini; however, it is shorter than isoform 1 (377 aa). Variants 1 and 2 differ only in the 3 amino acids. There is also no difference regarding the domain structure between variants. Both proteins have 2 Ubiquitin-Interacting Motif (UIM) domains. We also compared the protein sequence of human variant 1 with different species, namely, mouse and rat. Our Bioinformatic analyses showed that first 250 nucleotides are much conserved in all three species.

\section{Acknowledgments}

This research was supported by the Balikesir University, Scientific Research Projects Unit (BAP) (2014-109).

\section{References}

1. H. Lodish, A. Berk, P. Matsudaira, C.A. Kaiser, M. Krieger, M.P. Scott, S.L. Zipursky, J. Darnell, Molecular cell biology, (2004) 66-72.

2. J. Adams, The proteasome: structure, function and role in the cell, Cancer Treat. Rev., 1 (2003) 3-9.

3. J.D. Etlinger, A.L. Goldberg, A soluble ATP-dependent proteolytic system responsible for the degradation of abnormal proteins in reticulocytes, PNAS, 74 (1977) 54-58.

4. N. Benaroudj, P. Zwickl, E. Seemuller, W. Baumeister, A.L. Goldberg, ATP hydrolysis by the proteasome regulatory complex PAN serves multiple functions in protein degradation, Molecul. Cell, 11 (2003) 69-78.

5. J.E. Nelson, A. Loukissa, C. Altschuller-Felberg, J.J. Monaco, J.T. Fallon, C. Cardozo, Up-regulation of the proteasome subunit LMP7 in tissues of endotoxemic rats. J. Laborat. Clin. Med., 135 (2000) 324-331.

6. S. Türkoğlu, F. Köçkar, SP1 and USF differentially regulate ADAMTS1 gene expression under normoxic and hypoxic conditions in hepatoma cells, Gene, 575 1 (2016) 48-57.

7. M. Alper and F. Köçkar, Induction of Human ADAMTS-2 Gene Expression by IL-1 $\alpha$ is Mediated by a Multiple Crosstalk of MEK/JNK and PI3K Pathways in Osteoblast like Cells, Gene, 573 (2015) 321-327.

8. E.Tokay and F. Köçkar, 'In Silico and Expression analysis of URG-4/URGCP Gene in Different Cancer Cells, J.Appl. Biol. Sci., 2 (2015) 13-18.

9. J. Wang, M.A. Maldonado, The ubiquitin-proteasome system and its role in inflammatory and autoimmune diseases, Cell. Mol. Immunol., 34 (2006) 255-261.

10. Y. Uyanıkgil, C. Sümer Turanlıgil, Ubikitin-proteozom yolağının karsinojenezdeki rolü. ARŞiV, 19 (2010) 36.

11. G.P. Tuszynski, V.L. Rothman, M. Papale, B.K. Hamilton, J. Eyal, Identification and characterization of a tumor cell receptor for CSVTCG. a thrombospondin adhesive domain, J. Cell. Biol., 120 (1993) 513-521.

12. C. Wang, H. Fan, J. Zhou, M. Lu, J. Sun, Y. Song, H. Le, L. Jiang, B. Wang, Jiao, S5a binds to death receptor-6 to induce THP-1 monocytes to differentiate through the activation of the NF-kB pathway, J. Cell Sci., 127 (2014) 3257-3268.

13. A. Sparks, S. Dayal, J. Das, P. Robertson, S. Menendez, MK. Saville, The degradation of p53 and its major E3 ligase Mdm2 is differentially dependent on the proteasomal ubiquitin receptor S5a. Oncogene, (2013) 1-12.

14. R.K. Singh, S. Zerath, O. Kleifeld, M. Scheffner, M.H. Glickman, D. Fushman, Recognition and Cleavage of Related to Ubiquitin 1 (Rub1) and Rub1-Ubiquitin Chains by Components of the Ubiquitin-Proteasome System, Mol. Cell. Proteomics, 11 (2012) 1595-1611.

15. M. Elangovan, C. Oh, L. Sukumaran, C. Wójcik, Y.J. Yoo, Functional differences between two major ubiquitin receptors in the proteasome; S5a and hRpn13, Biochem. Biophy. Res. Comm., 396 (2010) 425-428. 
16. A. Arlt, I. Bauer, C. Schafmayer, J. Tepel, S.S. Müerköster, M. Brosch, C. Röder, H. Kalthoff, J. Hampe, M.P. Moyer, U.R. Fölsch, H. Schafer, Increased proteasome subunit protein expression and proteasome activity in colon cancer relate to an enhanced activation of nuclear factor E2-related factor 2 (Nrf2), Oncogene, 28 (2009) 3983-3996.
17. S.M. Pulukuri, C.S. Gondi, S.S. Lakka, A. Jutla, N. Estes, M. Gujrati, J.S. Rao, RNA interference -directed knockdown of urokinase plasminogen activator and urokinase plasminogen activator receptor inhibits prostate cancer cell invasion, survival, and tumorigenicity in vivo, J. Biol. Chem., 280 (2005) 36529-36540. 